\title{
Kebijakan Pembinaan Kesejahteraan Keluarga (PKK) Dalam Melaksanakan Kegiatan Pola Asuh Anak Dan Remaja Desa Jangkang Kecamatan Bantan Kabupaten Bengkalis
}

\author{
${ }^{1}$ Septa Juliana, ${ }^{2}$ Made Devi Wedayanti \\ ${ }^{12}$ Universitas Islam Riau \\ e-mail :madedeviwedayanti@ soc.uir.ac.id
}

\begin{abstract}
Abstrak
Penelitian ini bertujuan untuk melihat kebijakan Pembinaan Kesejahtraan Keluarga dalam Melaksanakan Kegiatan Pola Asuh Anak dan Remaja Desa Jangkang kecamatan Bantan Kabupaten Bengkalis dan penelitian ini dilaksanakan dengan mengunakan metode penelitian survey, tingkat eksplanasinya deskriftif serta mengunakan data kualitatif. Peneliti mewawancarai secara langsung dan secara mendalam kepada key informant yang di anggap paling mengetahui Kegiatan Pola Asuh anak dan Remaja dengan mengunakan teknik purposive sampling. Secara praktis,hasil penelitian ini bermanfaat sebagai bahan informasi bagi Pemerintah Desa jangkang khususnya Pembinaan Kesejahtraan Keluarga terkait Program yang dilaksanakannya. Hasil penelitian menunjukkan Masih kurang pahamnya masyarakat dengan kegiatan Kegiatan Pembinan Kesadaran Bela Negara dan banyak orang tua berfikiran Pola Asuh anak dan Remaja ini dilakukan disekolah saja bukan dirumah. Oleh sebab itu kegiatan dalam program ini harus dapat ditingkatkan kembali.
\end{abstract}

Kata Kunci:Pola Asuh Anak dan Remaja, Pembinaan Kesejahtraan Keluarga

Abstrack

This study aims to see the policy of Family Welfare Development in Implementing Parenting Activities for Children and Adolescents in Jangkang Village, Bantan District, Bengkalis Regency and this research was conducted using survey research methods, descriptive level of explanation and using qualitative data. Researchers interviewed directly and in-depth key informants who were seen from the dangers in parenting activities for children and adolescents using purposive sampling technique. In practical terms, the results of this study are useful as information material for the Village Government, especially the Family Welfare Development related to the program it carries out. The results showed that the community still lacks understanding of the State Defense Awareness Building activities and many parents think that parenting for children and adolescents is done at school, not at home. Therefore, activities in the program must be increased again..

Keywords :parenting and youth, family welfare development

\section{PENDAHULUAN}

Berdirinya Negara Kesatuan Republik Indonesia memiliki tujuan yang sangat mulia sebagaimana yang tercantum dalam pembukaan Undang-Undang Dasar Negara Republik Indonesia Tahun 1945 yaitu untuk melindungi segenap bangsa Indonesia dan seluruh tumpah darah Indonesia dan untuk memajukan kesejahteraan umum, mencerdaskan kehidupan bangsa, dan ikut melaksanakan ketertiban dunia yang berdasarkan kemerdekaan, perdamaian abadi dan keadilan sosial. Negara menyusun bahwa kemerdekaan secara bertingkat mulai dari pemerintah Pusat, Pemerintah Daearah dan pemerintah Desa. Desa adalah kesatuan masyarakat hukum yang memiliki batas wilayah yang berwenang untuk mengatur dan mengurus urusan pemerintahan, kepentingan masyarakat setempat berdasarkan prakarsa masyarakat, hak asal usul, dan/atau hak tradisional yang diakui dan dihormati 
dalam sistem pemerintahan Negara Kesatuan Republik Indonesia [2] Keluarga merupakan suatu kelompok yang menjadi bagian dalam masyarakat yang bertempat tinggal di desa maupun di kota, dalam keluarga terdiri dari ayah, ibu, dan anak, salah satu yang berperan dalam membina keluarga adalah ibu. Sebagai seorang wanita, ibu dituntut untuk mempunyai waktu yang lebih mengurus anak disbandingkan dengan ayah. Sedangkan masyarakat merupakan tempat anak-anak hidup dan bergaul dengan orang dewasa yang memiliki peran dan pengaruh tertentu dalam pembentukan pribadi dan prilaku anak. Didalam Pasal 21 dan pasal 27 Undang-Undang Dasar 1945 menjamin adanya kesamaan hak dan kewajiban bagi penduduk tanpa membeda-bedakan apakah pria ataupun wanita, dalam bidang pekerjaan, kesehatan, politik, dan hukum, serta hak perorangan. Oleh karna itu maka pemerintah telah membentuk berbagai program yang dapat membantu kaum perempuan yang ada dipusat,daerah,kabupaten hingga ke desa ikut berperan serta dalam pembangunan yang berupaya untuk meningkatkan kesejahteraan keluarga yang bernama Pemberdayaan Pembinaan Kesejahtraan Keluarga yang di disingkat dengan nama PKK, PKK adalah organisasi kemasyarakatan yang memberdayakan wanita untuk turut berpartisipasi dalam pembangunan Indonesia PKK terkenalakan 10 program pokok.

10 Program Pokok PKK pada hakekatnya merupakan kebutuhan dasar manusia, yaitu :

1. Penghayatan dan Pengamalan Pancasila

2. Gotong Royong

3. Pangan

4. Sandang

5. Perumahan dan Tata laksana Rumah Tangga

6. Pendidikan dan Ketrampilan

7. Kesehatan

8. Pengembangan Kehidupan Berkoperasi

9. Kelestarian Lingkungan Hidup

10. Perencanaan Sehat

Dari Program Pokok PKK tersebut Desa Jangkang berhasil meraih juara satu sebagai desa percontohan oleh pihak Kabupaten sebagai Pola Asuh Anak dan Remaja (PAAR) sesuai dengan program pokok yang pertama yaitu penghayatan dan pengamalan pancasila.

Pola asuh anak dan remaja merupakan salah satu program PKK yakni usaha orang tua dalam membina anak dan membimbing anak baik jiwa maupun raganya sejak lahir hingga dewasa. Selain itu yang dimaksud dengan pola asuh adalah kegiatan kompleks yang meliputi banyak prilaku pesifik yang bekerja sendiri atau bersama sama yang memiliki dampak pada anak. Sebelum melaksanakan Pola Asuh Anak dan remaja terlebih dahulu orang tua diberikan penuluhan dan pembinaan yang dilakukan oleh tingkat kecamatan dan kabupaten dan di selengarakan oleh tingkat desa yaitu desa Jangkang Kecamatan Bantan Kabupaten Bengkalis yang dibentuk oleh PKK Desa Jangkang. Daftar nama Orang tua yang tercantum sebagai warga biunaan Pola Asuh Anak dan Remaja sebagai berikut :

Tabel 1

Daftar Nama Keluarga Binaan Pola Asuh Anak dan Remaja

\begin{tabular}{|c|c|c|}
\hline No & Nama Kepala Keluarga Binaan PAAR & Warga Dusun \\
\hline 1 & ( & Mekar Indah \\
\hline 2 & Sarjuni & Mekar Indah \\
\hline 3 & Basri & Mekar Indah \\
\hline 4 & Karim & Mekar Indah \\
\hline 5 & Yardin & Mekar Indah \\
\hline 6 & Arnok & Mekar Indah \\
\hline
\end{tabular}




\begin{tabular}{clc}
\hline 7 & Yanto & Mekar Indah \\
\hline 8 & Kusen & Mekar Indah \\
\hline 9 & Boyman & Tambak Rejo \\
\hline 10 & Ran & Tambak Rejo \\
\hline 11 & Yani & Tambak Rejo \\
\hline 12 & Din & Asli \\
\hline 13 & Eko & Asli \\
\hline 14 & Busri & Utama Jangkang \\
\hline 15 & Ipin & Utama Jangkang \\
\hline 16 & Seno & Tambak Rejo \\
\hline 17 & Sapri & Tambak Rejo \\
\hline 18 & Imron & Tambak Rejo \\
\hline 19 & Heri & Utama Jangkang \\
\hline 20 & Azuar & Tambak Rejo \\
\hline 21 & Husin & Mekar Indah \\
\hline 22 & Arpin Hero & Utama Jangkang \\
\hline 23 & Buhari & Asli \\
\hline 24 & Suwandi & Mekar Indah \\
\hline & &
\end{tabular}

Tujuan Pola Asuh Anak dan Remaja (PAAR) meliputi 1) untuk mencapai pembinaan kesadaran bela negara (PKBN). 2) pencegahan dan Penyalahgunaan Narkoba. 3)Mencegah kekerasan dalam rumah tangga (KDRT). 4) Peran orang tua dalam menerapkan pola asuh anak dengan cinta dan kasih sayang. 5) Penanaman Toga (Tanaman Obat Keluarga)

Program PKK (Pembinaan Kesejahtraan Keluarga) dalam menjalankan kegiatan Pola Asuh Anak dan Remaja sebagai berikut:

Tabel 2

Data Kegiatan PKK didalam Program Pola Asuh Anak dan Remaja

\begin{tabular}{lll}
\hline No & Pogram Kegiatan & Jenis Kegiatan \\
\hline 1 & Pencapaian Pembinaan Kesadran Bela Negara & Sosialisasi \\
\hline 2 & Pencegahan dan Penyalahgunaan Narkoba & Sosialisasi \\
\hline 3 & Pencegahan Kekerasan dalam Rumah Tangga & Pembinaan \\
\hline 4 & $\begin{array}{l}\text { Peran Orang Tua dalam menerapkan pola asuh } \\
\text { anak dengan cinta dan kasih saying }\end{array}$ & Pembinaan \\
\hline
\end{tabular}

\section{Sumber : Kantor Desa Jangkang Kabupaten Bengkalis}

Merujuk pada uraian latar belakang diatas maka pertanyaan peneliti adalah" Program apa yang diterapkan PKK untuk Menjalankan Kegiatan PAAR”

\section{METODE}

Penelitian ini dilakukan di Desa Jangkang Kecamatan Bantan kabupaten Bengkalis selaku pengerak Program Pola Asuh Anak dan Remaja. Penelitian ini dilaksanakan dengan mengunakan metode penelitian survey, tingkat eksplanasinya deskriftif serta mengunakan analisis data kualitatif. Peneliti mewawancarai secara langsung dan secara mendalam kepada key informant yang dianggap 
paling mengetahui Program Pola Asuh Anak dan Remaja dengan mengunakan teknik provosive sampling. Berikut table informen penelitian.

Tabel 3

Daftar Nama Informen dan key informant dalam Program Pola Asuh Anak dan Remaja

\begin{tabular}{llccc}
\hline No & Nama & Jabatan & & Jumlah \\
\hline 1 & Dian Martinah S.Pd & Ketua TP.PKK & Key Informant & 1 \\
\hline 2 & Nurbaini S.Pd & Ketua PAAR & Informant & 1 \\
\hline 3 & Buginem & Anggota PAAR & Informant & 1 \\
\hline 4 & Yani & Warga Binaan PAAR & Informant & 1 \\
\hline 5 & Karim & Warga Binaan PAAR & Informant & 1 \\
\hline & & & 5 & \\
\hline
\end{tabular}

Sumber : Data Olahan peneliti Tahun 2020

\section{HASIL DAN PEMBAHASAN}

\section{A. Pencapaian Pembinaan Kesadaran Bela Negara (PKBN)}

Kegiatan Pencapaian Pembinaan Kesadaran bela Negara ini merupakan upaya yang sangat penting dilaksanakan agar masyarakat mengetahui apa yang baik dan apa yang buruk sesuai dengan program PKK yang pertama yaitu menerapkan penghayatan dan pengamalan Pancasila. Berdasarkan hasil penelitian yang kami lakukan dilokasi penelitian tentang Pencapaian Pembinaan Kesadaran Bela Negara ini Desa Jangkang sudah melakukan secara bertahap kepada setiap dusun yang ada di Desa Jangkang yaitu Dusun Mekar Indah,Dusun Tambak Rejo,Dusun Utama Jangkang serta Dusun Asli, dari beberapa dusun disini terdapat beberapa suku adat dan agama, akan tetapi saling akur dan saling bersatu untuk menyatukan asa tunusa satu bangsa dan tidak lepas dari Bahineka Tunggal ika. Sosialisasi ini diikuti oleh seluruh PAAR binaan Desa Jangkang agar keluarga binaan mengetahui materi yang telah diprogramkan oleh PAAR tersebut.

Dian MartinahS.Pd selaku Ketua TP-PKK mengtakan dalam wawancara bahwa kegiatan ini sudah dijalankan sesuai dengan rencana serta kegiatan ini bertujuan untuk tercapainya pembinaan kesadaran bela negara. Salah satu Pencapaian Pembinaan kesadaran Bela Negara dengan cara memperhatikan kebersihan lingkungan, kesehatan dan kedamaian disetiap lingkungan keluarga serta meningkatkanTanaman Obat keluarga (toga),akan tetapi masih banyaknya masyarakat kita yang kurang paham dengan hal-hal tersebut dikarenakan masih banyak masyarakat yang berfikir primitif hal tersebut lanjut diungkapkan oleh Dian Martinah.

Ditempat yang berbedaketua PAAR Nurbaini mengatakan "kegiatan ini Insya Allah sudah berjalan dengan baik walaupun belum tercapai yang terbaik numun beliau berharap semoga seluruh kader PAAR mengambil manfaat untuk kegiatan ini, dan nantinya untuk diterapkan dan disosialisasikan kepada yang lain dan harapannya supaya keluarga PAAR binaan bias menjadi contoh keluarga yang lain, khususnya keluarga yang ada di desa jangkang.

Buginem selaku anggota PAAR mengatakan disaat diwawancarai beliau mengatakan pensosialisasian ini sudah diterapkan di desa jangkang dengan baik sesuai dengan materi meski dalam keadaan covid 19 ini namun tetap dijalankan dengan menggunakan protocol kesehatan. Ditempat yang berbeda saudara Yani selaku Warga Binaan PAAR mengemukakan pendapatnya saat diwaancarai bahwa "saya merasa puas dengan adanya Kegiatan Pembinaan Kesadaran Bela Negara sehingga kita benar-benar merasa bersatu dalam satu negara,Bersatu disini maksudnya sama-sama menjalankan dan menerap kanapa yang disampaikan disaat pensosialisasian dilaksanakan,paling tidak menerapkan 
kesehatan kebersihan ,kekompakan dan lai-lain, dan juga waktu kita disaat berkumpul sangatlah berharga dengan adanya kegiatan kegiatan seperti ini”. Karrim selaku warga binaa PAAR juga mengatakan hal yang sama disaat diwawancarai "dengan adanya kegiatan sosialisasi ini kita merasa hidup bersatu karena dari berbagai hal kita tidak tau menjadi tau seperti manfaat kebersihan dan manfaat kebersamaan".

\section{B. Pencegahan dan Penyalahgunaan Narkoba}

Dalam membahas hal pencegahan dan penyalahgunaan Narkoba ini memang rada sulit untuk dibahas karena desa Jangkang merupakan pusat pengelolaan barang haram hal ini dikarenakan Desa Jangkang berada ditepian pantai dan dengan mudahnya barang haram tersebut memasuki dari negara tetangga oleh orang-orang yang tidak bertanggung jawab, ini akan tetapi secara bertahap Sosialisasi masalah ini sudah dijalankan dengan baik sesuai dengan diadakan beberapa kegiatan terhadap anak dan remaja yang ada didesa jangkang. Hal ini diketahui disaat peneliti mewawancarai Ketua TP-PKK Desa Jangkang MartinahS.Pd, beliau mengatakan Alhamdulillah sekarang remaja Desa Jangkang cendrung lebih banyak kearah positif tidak ada lagi yang suka nongkrong sampai larut malam, karna aktifitas yang padat disiang hari seperti olahraga futsal volly dan tahfis Qur'an, apalagi sekrang di Jangkang sudah ada Kampung Qur'an, haltersebut sejalan di ungkapkan oleh Nurbaini selaku Ketua PAAR beliau mengatakan "kegiatan pencegahan dan penyalahgunaan Norkoba ini sudah berjalan dengan baik namun belum menjadi terbaik hal ini kita lakukan dengan cara berlahan-lahan, Nurbaini menambahkan untuk merubah kejalan yang baik memang rada sulit akan tetapi kami akan tetap berusaha yang sebaik mungkin untuk merubah yang kurang baik menjadi lebih baik, hal ini dilakukan dengan menyediakan beberapa kegiatan utuk anak muda dan anak-anak" Buginem selaku anggota PAAR juga mengatakan sosialisasi ini dilakukan Dengan pembinaan mengenai pencegahan penyalahan narkoba ini tentunya diharapkan masyarakat lebih tau dan paham tentang bahaya narkoba yang selama ini banyak orang tua yang tidak paham dengan bahaya narkoba sekarang sudah memahami sedikit demi sedikit. Ditempat yang berbeda Yakni selaku Anggota binaan PAAR mengatakan bahwa "kegiatan pencegahan dan penyalahgunaan narkoba ini sudah berjalan dengan baik hal ini dengan adanya berdirinya kampung kuran di desa jangkang sehingga kami selaku orang tua merasa terbantu untuk mendidik anak tentang agama guna menghindari hal-hal yang tidak diinginkan seperti narkoba"

Karim selaku keluarga binaan PAAR juga mengatakan pencegahan dan penyalahgunaan narkoba ini sudah berjalan dengan baik "saya juga merasa sangat terbantu dengan adanya kegiatan ini dibarengi dengan menguatkan kegiahtan keagamaan seperti adanya kampung Quran ini sehingga anak anak dan remaja diisi dengan kesibukan hal yang baik.

\section{Pencegahan Kekerasan dalam Rumah Tangga}

Untuk Peningkatan Pencegahan Kekerasan Dalam Rumah Tangga Pemerintah Desa jangkang melalui Program PKK menerapkan Penghayatan dan pengamalan Pancasila dengan cara menjalankan kegiatan Pola Asuh Anak dan Remaja dengan cara membinahal yang baik yang akan mempengaruhi kekerasan dalam rumah tangga. Berdasarkan hasil penelitian yang kami lakukan dilokasi penelitian dalam hal mencegah kekerasan dalam rumah tangga tersebut sudah tercapai walaupun memang untuk menuju kesempurnaan masih dalam usaha untuk mencapainya. Sebagaimana yang dikatakan oleh Ketua TP-PKK Desa Jangkang Dian MartinahS.Pd dalam wawancara beliau mengatakan " kalau berbicara Pencegahan Kekerasan dalam rumah Tangga Insya Allah sudah berjalan dengan baik, sesuai dengan kegiatan-kegiatan yang kami lakukan yaitu dengan memadukan wirit yasin mingguan ibu-ibu pengajian dusun Mekar indah dan dusun Tambak Rejo" terjadinya PKDRT atau perbuatan terhadap sesorang terutama perempuan mengakibatkan timbulnya kesengsaraan atau penderitaan secara fisik, seksual, psikologis atau penelataran rumah tangga termasukan caman untuk melakukan perbuatan 
pemaksaan, perampasan kemerdekaan, hal tersebut di ungkapkan oleh Dian MartinahS.Pd. beliau berharap kegiatan yang telah dilakukan dapat bermanfaat bagi masyarakat kader PKK dan keluarga PAAR serta dapat meningkatkan motivasi dalam mengabdi dan membangun Desa Jangkang lebih baik kedepannya.

Senada yang diungkapkan NurbainiS.Pd selaku ketua PAAR mengatakan melalui kegiatan pengajian ini memberikan informasi dan motivasi tentang pencegahan KDRT, sehingga menguatkan ketahanan keluarga yang merupakan pondasi kokoh masyarakat, membuat masyarakat lebih stabil dan focus meningkatkan kualitas hidup, kualitas pendidikan,kualitas perekonoman. Buginem selaku Anggota PAAR juga mengatakan pencegahan kekerasan rumah tangga ini sudah berjalan dengan baik. " saya selaku anggota PAAR sudah merasakan manfaatnya karena kegiatan ini diisi dengan beberapa kegiatan seperti wirit yasin mingguan dan setiap satu bulan sekali diisi dengan ceramah agama" Yani juga mengemukakan hal yang sama pencegahan kekerasan rumah tangga ini dilakukan dengan baik dan jenis kegiatanya bukan hanya untuk ibu-ibu akan tetapi untuk kaum bapak juga diterapkan sehingga sama-sama mendapatkan pembekalan agama didalam rumah tangga. Karim juga berpendapat bahwa melalui kegiatan pengajian ini bukan hanya dilakukan untuk menambahkan keilmuan saja akan tetapi bias saling bertukar pikiran antara satu dengan yang lain sehingga kita tidak terpaku dengan satu pendapat dan kita bias menerima pendapat orang lain serta berjiwa besar apa bila pendapat kita tidak disetujui, hal itu merupakan kebiasaan sehingga menghindari dari kekerasan dalam rumah tangga, hal ini di dapat disaat penulis mewawancarai Karim selaku warga binaan PAAR.

\section{Peran Orang Tua Dalam Menerapkan Pola Asuh Anak Dengan Cinta Dan Kasih Sayang}

Orang tua merupakan seseorang yang mendampingi dan membimbing anak dalam beberapa tahap pertumbuhan, yaitu mulai dari merawat, melindungi, mendidik, mengarahkan dalam kehidupan baru anak dalam setiap tahapan perkembangannya untuk masa berikutnya. Perkembangan manusia dapat dilihat dari aspek fisik dan psikis, sosial dan spiritual, yang paling menentukan bagi keberhasilan kehidupannya, sangat ditentukan oleh lingkungan keluarga.Lingkungan keluarga yang kondusif menentukan perkembangan pribadi, penyesuaian diri, kemampuan bersosialisasi, kecerdasan, kreativitas, moral, juga peningkatan kapasitas diri menuju batas-batas kebaikan dan kesempurnaan dalam ukuran kemanusiaan. Keluarga merupakan lembaga sosial yang paling awal dikenal dan dekat dengan anak, hal ini menjadikan keluarga sebagai peran utama dalam pendidikan dan proses pembentukan kepripribadian seorang anak. Karena pada dasarnya manusia itu memiliki potensi yang positif untuk berkembang ,akan tetapi potensi itu bias teraktualisasikan atau tidak, sangat ditentukan oleh peran keluarga Kemudian pengasuhan merupakan tugas membimbing, memimpin, atau mengelola. Dalam hal pembinaan peran orang tua ini merupakan hal yang sangat penting bagi para orang tua. Dian S.Pd selaku Ketua TP-PKK desa Jangkang saat diwawanancarai mengatakan kegiatan ini sudah dilaksanakan dengan cara menjalankan mendampingi dan membimbing anak dalam beberapa tahap pertumbuhan, yaitu mulai dari merawat, melindungi, mendidik, mengarahkan dalam kehidupan baru anak dalam setiap tahapan perkembangannya untuk masa berikutnya. Selanjutnya Nurbaini mengatakan kegiatan ini kita lakukan rutin karena anak merupakan generasi penerus maka dari itu "kita tetap menerapkan pola asuh dengan cinta kasih saying seperti memberikan pelatihan-pelatihan yang bermanfaat dan cara membersihkan diri dan lingkungan. Begitu juga yang diungkapkan oleh yakni selaku anggota PAAR binaan kegiatan ini cukup baik dilakukan agar kita bisa terhindar dari segala penyakit, senada yang diungkapkan oleh karim selaku anggota keluarga binaan, "saya merasa puas dengan penerapan Peran orang Tua sama anak ini karena dari hal ini kita selaku orang tua lebih menyayangi yang muda,dan yang muda menghormati yang muda 


\section{KESIMPULAN}

Pola asuh orang tua memiliki pengaruh yang besar terhadap perkembangan moral anak ketika dewasa. Sayangnya, banyak sekali orang tua yang tidak sadar dengan tindakan yang mereka lakukan kepada sikecil. Banyak dari para orang tua yang menerapkan pola asuh salah karena berpatokan pada pengalaman masa lalu yang pernah mereka rasakan maka dari itu didalam Menjalankan Pelaksananyang dilakukan oleh PKK dengan tujuan agar masyarakat Desa Jangkang ini bias menerapkan Pola Asuh anak dan Remaja dengan baik sesuai dengan Program PKK tersebut sesuai dengan Penghayatan dan Pengamalan Pancasila. Berdasarkan observasi dan hasil wawancara dengan berbagai informen maka ditemukan kendala-kendala dalam Menjalanakan Pelaksanakan Kegiatan Program Pola Asuh Anak dan Remaja Desa Jangkang yaitu:

1. Masih kurang pahamnya masyarakat dengan kegiatan Kegiatan Pembinan Kesadaran Bela Negara, dan masih banyak masyarakat yang berfikiran primitif tentang bela Negara.

2. Masih banyak orang tua berfikiran Pola Asuhanka dan Remaja ini dilakukan disekolah saja bukan dirumah masing-masing.

\section{SARAN}

Adapun saran yang dapat dijadikan masukan dalam Pola Asuh Anak dan Remaja Desa Jangkang ini yakni :Pertama. Program Ini merupakam program yang berjalan dengan baik,oleh karena itu ditingkatkan lagi kegiatan-kegiatan yang dilakukan dan dipertahankan apa yang sudah dihasilkan dalam kegiatan ini.Kedua, Bagi Ketua PAAR tentukan jumlah masyarakat yang pantas menjadi masyarakat binaan PAAR dan di cantumkan dengan jelas syarat-syarat atau orang-orang yang pantas menjadi warga binaan PAAR.

\section{DAFTAR PUSTAKA}

[1]. Sugiono . (2003). Metode Penelitian Administrasi. Bandung: Alfabeta

[2]. Wasistiono, Sadu\&Irwan, M, Tahir. (2006). Prospek Pengembangan Desa. Fokusmedia: Bandung .

[3]. Husnatul Janah. Bentuk pola asuh orang tua dalam menanamkan prilaku moral pada anak usia dini dikecamatan Ampek Angkek. Jurnal Sosietas Vol 5 No 2

[4]. Muqorrobin Ahmad latief Zulfikar. (2016). Pengaruh Pola asuh Orang tuaTerhadap KelakuanRemaja Siswa Kelas X dan XI SMKN 2 Malang

[5].Qurrotaayun Ayu. (2017). Pola Asuh Orang Tua dan Metode Pengasuhan Dalam Membentuk Kepribadian Anak, Vol. 5 No. |Januari-Juni

[6]. Gunawan Imam. (2015). Metode penelitian Kualitatif Teori dan praktek. Jakarta, cetak ketiga: PT Bumi Nusantara.

[7]. Sugiono. (2003). Metode Penelitian Administrasi. Bandung: Alfabeta 
[8]. Hasnah .H. (2016). Teknik-Teknik Observasi. Jurnal At-Taqqadum, 8 (1) 21-46

[9]. Moelong,lexy J. (2007). Metode Penelitian kualitatif. Bandung: PT Remaja Rosda Karya offset

[10]. Madjia Rahardjo, M. (2011). Metode Pengumpulan Data Penelitian Kualitatif. Mudiardjo.uinmalang.ac.id. diakses 08 Juli 2020. 